Chirurgia (2019) 114: 73-82

No. 1, January - February

Copyright $@$ Celsius

http://dx.doi.org/10.21614/chirurgia.114.1.73

\title{
Traumatic Diaphragmatic Lesions - Considerations Over a Series of 15 Consecutive Cases
}

\author{
Vlad-Andrei Porojan', Oana Ilona David', Ionut Simion Coman', Elena Violeta Coman ${ }^{1,2}$, Diana Andreea Draghici', \\ Cristian Popescu ${ }^{1,2}$, Marius Paraschiv ${ }^{1}$, Valentin Titus Grigorean ${ }^{1,2}$
}

'General Surgery Department, "Bagdasar-Arseni" Emergency Hospital, Bucharest, Romania

${ }^{2} 10^{\text {th }}$ Surgical Department, "Carol Davila" University of Medicine and Farmacy, Bucharest, Romania

Corresponding author:

Oana llona David, MD

General Surgery Department

"Bagdasar-Arseni" Emergency Hospital

Berceni Road, 12, Bucharest, Romania

E-mail: davidoana_29@yahoo.com

Received: 17.08 .2017

Accepted: 01.11.2017

\section{Rezumat}

Leziunile diafragmatice traumatice - consideratii asupra unei serii de 15 cazuri consecutive

Introducere: Leziunile diafragmatice sunt produse prin traumatisme toraco-abdominale închise sau deschise. Acestea sunt leziuni potențial letale prin hernierea organelor abdominale în cavitătile pleurale şi prin severitatea leziunilor asociate. Scopul acestui studiu a fost analizarea manifestărilor clinice şi a managementului pacienților internați în clinica noastră cu diagnosticul de ruptura traumatică a diafragmului.

Material şi metodă: Am efectuat un studiu retrospectiv pe o perioadă de 5 ani, în care am inclus pacienții internați cu leziuni diafragmatice acute, internați în Clinica de Chirurgie Generală a Spitalului de Urgență "Bagdasar-Arseni”. Am analizat repartiția pe sexe şi vârstă, mecanismul traumei, localizarea, timpul până la diagnostic, leziunile concomitente, tratamentul chirurgical şi rezultatele.

Rezultate: Au fost incluşi în studiu 15 pacienți (8 bărbați, 7 femei, vârstă medie de 42 ani) cu rupturi diafragmatice (13 ale hemidiafragmului stâng, 2 ale celui drept), produse prin traumatisme închise (8 cazuri) sau deschise (7 cazuri). Leziunile diafragmatice închise au avut dimensiuni mai mari, producând hernierea viscerelor abdominale la 6 bolnavi. Sutura directă a fost efectuată la toți cei 15 pacienți, abordul prin laparotomie mediană fiind preferat de cele mai multe ori. Rata mortalității a fost de $20 \%$, cauza principală fiind leziunile concomitente foarte grave.

Concluzii: Deşi rupturile traumatice diafragmatice se asociază 
frecvent cu traumatisme craniene şi toraco-abdominale foarte grave, diagnosticul şi tratamentul prompt instituit poate duce la rezultate bune.

Cuvinte cheie: leziuni traumatice diafragmatice, traumatism deschis, traumatism închis

\begin{abstract}
Introduction: Diaphragmatic injuries are produced by blunt or penetrating thoracoabdominal trauma. They are potentially life-threatening due to the herniation of abdominal organs into the pleural cavities and severe associated lesions. The aim of this retrospective study was to analyse the clinical presentation and management of patients admitted with diaphragmatic rupture in our institution.

Material and Method: We performed a 5-year retrospective study of patients admitted with acute blunt or penetrating diaphragmatic rupture in the Department of General Surgery of "BagdasarArseni" Emergency Hospital. We have studied sex, age, mechanism of trauma, side-location, timeto-diagnosis, concomitant injuries, surgical treatment and outcome.

Results: Fifteen patients (8 males, 7 females, mean age: 42 years) with diaphragmatic rupture (left-side: 13, right-side: 2) following blunt (8 patients) or penetrating (7) trauma were included. Patients with blunt diaphragmatic injury had larger tears and abdominal viscera herniation was observed in 6of these cases. A direct suture was performed for all 15 patients. Laparotomy was the surgical approach preferred in most of the cases. Mortality rate was $20 \%$, mainly caused by severe associated lesions.

Conclusion: Although traumatic diaphragmatic lesions are frequently associated with severe cerebral and thoraco-abdominal trauma that is also the main cause of death, a prompt diagnosis and treatment can lead to good outcome.
\end{abstract}

Key words: traumatic diaphragmatic lesions, penetrating trauma, blunt trauma

\section{Introduction}

Traumatic diaphragmatic rupture is an unusual type of trauma, often representing a diagnostic and therapeutic challenge (1). Accurate estimates of traumatic diaphragmatic rupture incidence are unlikely to be performed, this particular type of trauma generating a high proportion of prehospital deaths or being highly under diagnosed. Diaphragmatic trauma is often missed in patients with severe associated trauma. Furthermore, conventional imaging techniques have low sensitivity in diagnosing traumatic lesions of the diaphragm, initial CT scan being inaccurate in 13 to $63 \%$ of cases (2-6). The misdiagnosis may lead to strangulation of the intrathoracic herniated abdominal viscera, with a mortality rate between 30 and 60\% (7). Diaphragmatic rupture is either produced by blunt trauma or penetrating injuries (8). Approximately 1- $7 \%$ of patients suffering blunt trauma associate diaphragmatic injuries, whereas up to $15 \%$ of patients victims of penetrating trauma have diaphragmatic involvement (9-11). Still, blunt diaphragmatic trauma is more common $(75 \%)$ than penetrating diaphragmatic trauma, having a variable incidence, depending on regional socio-economic conditions $(3,8,12,13)$.

Blunt diaphragmatic trauma occurs mostly in car crash victims or secondary to fall from heights $(3,8,14)$. The sudden increase in abdominal pressure, generating excessive pressure on the diaphragm, is the main physiopathological mechanism determining diaphragmatic injury, particularly lesions located in the middle of the diaphragmatic dome. However, lateral shearing of the 
diaphragm may also occur as well as its avulsion from muscular points insertion, in patients suffering side impacts $(15,16)$. Leftsided injuries are more common (75\%) as compared to right-sided injuries (13\%) and bilateral injuries (2\%) (17). Abdominal viscera, most frequent the stomach and large bowel (18), can herniate through large diaphragmatic tears, thus leading to acute cardiorespiratory failure. Diaphragmatic trauma is rarely single; it is usually associated with other lesions of the surrounding structures, including the lungs, the spleen, the liver and the bowels. Furthermore, it often associates rib fractures and pelvic girdle fractures (16).

Penetrating diaphragmatic injuries mostly occur in stab or gunshots victims, the latest having a higher injury severity but are very rare in non-combat areas. Usually, penetrating trauma causes small tears within the diaphragmatic muscle. Unrecognized and left untreated, minor ruptures may increase with time, after ward developing towards diaphragmatic hernias (1).

Mortality associated with diaphragmatic trauma varies between 4.3 and $37 \%(12,13)$ furthermore emphasizing the need for prompt recognition and effective surgical repair of even the smallest diaphragmatic injury.

The purpose of our study is assessing the right diagnosis and therapeutical plan to be performed in case of traumatic diaphragmatic lesions, focusing on the patient's haemodynamic status. We aim to identify measures that may decrease mortality, while taking into account the trauma mechanism as well as the associated lesions.

\section{Material and Method}

We retrospectively analysed patients with acute diaphragmatic injury admitted and operated in the General Surgery Department of "Bagdasar-Arseni" Emergency Clinical Hospital. During the study period (from January 1st of 2012 to $31^{\text {st }}$ December of 2016), we reviewed all polytraumatized patients, including in the study group those diagnosed either pre- or intraoperative with blunt or penetrating acute diaphragmatic injuries - fifteen subjects. Patients receiving delayed surgical treatment for posttraumatic diaphragmatic hernias were excluded from the study group.

We studied the type of trauma (blunt/ penetrating) as well as its mechanism, the time from admission till surgical intervention, the accuracy of the preoperative diagnosis assessing the diaphragmatic injury. Furthermore, we discussed the rupture's location (left/right diaphragm), as well as the number and size of injuries, the associated lesions and their relationship to surgical treatment and postoperative outcome.

\section{Results}

This study group was equally distributed by gender, including 8 males and 7 females, ages between 11 and 60 with a mean age of 42 . Out of 15 cases, 8 were victims of blunt trauma and 7 suffered from penetrating trauma (Table 1).

Table 1. Main characteristics of the study group

\begin{tabular}{lr}
\hline Characteristic & Value \\
\hline Age (years) & \\
$\quad$ Range & $11-85$ years \\
Mean & 42 years \\
\hline $\begin{array}{l}\text { Gender } \\
\quad \text { Male }\end{array}$ & $8(53.3 \%)$ \\
$\quad$ Female & $7(46.7 \%)$ \\
\hline Type of trauma & \\
$\quad$ Penetrating & $7(46.7 \%)$ \\
$\quad$ Blunt & $8(53.3 \%)$ \\
Side & \\
$\quad$ Left hemidiaphragm & $13(86.7 \%)$ \\
Right hemidiaphragm & $2(13.3 \%)$ \\
$\quad$ Both & \\
\hline Rupture size (no. of patients ) & \\
$\quad<5$ cm & $7(46.7 \%)$ \\
$5-10 \mathrm{~cm}$ & $3(20.0 \%)$ \\
$\quad>10 \mathrm{~cm}$ & $5(33.3 \%)$ \\
\hline Haemodynamic instability (no. of patients ) & \\
Yes & $8(53.3 \%)$ \\
No & $7(46.7 \%)$ \\
\hline ISS & \\
Mean & 32.6 \\
\hline Hospitalisation (days) & \\
Mean & 14.8 days \\
\hline
\end{tabular}


All patients with blunt diaphragmatic lesions were car crash victims (drivers or passengers), 6 of them having left-side diaphragmatic lesions while the remaining 2 had right-side diaphragmatic lesions. Three patients were preoperatively diagnosed with diaphragmatic lesions, via imaging techniques (chest X-ray and chest CT showing large diaphragmatic ruptures leading to abdominal visceral herniation into the thoracic cavity) (Figs. 1-4). Three other patients were haemodynamically unstable with imminent cardiac arrest at hospital admission, therefore being rushed into the operating room without having performed any imagistic tests.

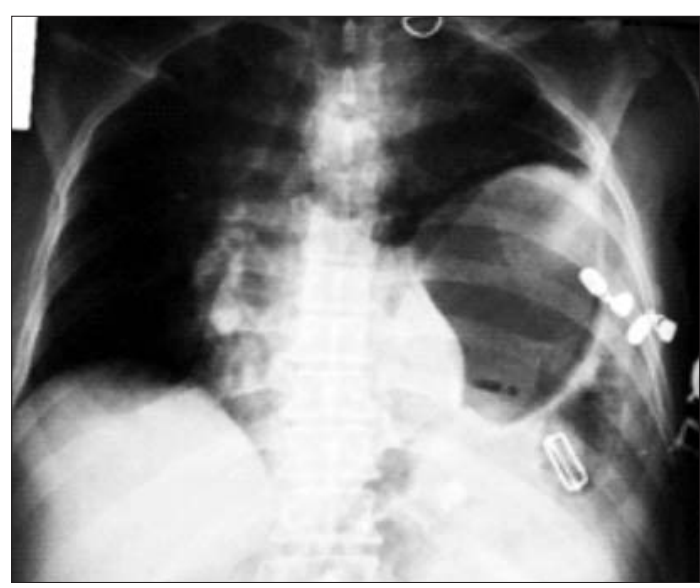

Figure 1. Blunt thoracic trauma. Anterior chest X-Ray that shows transdiaphragmatic gastric herniation

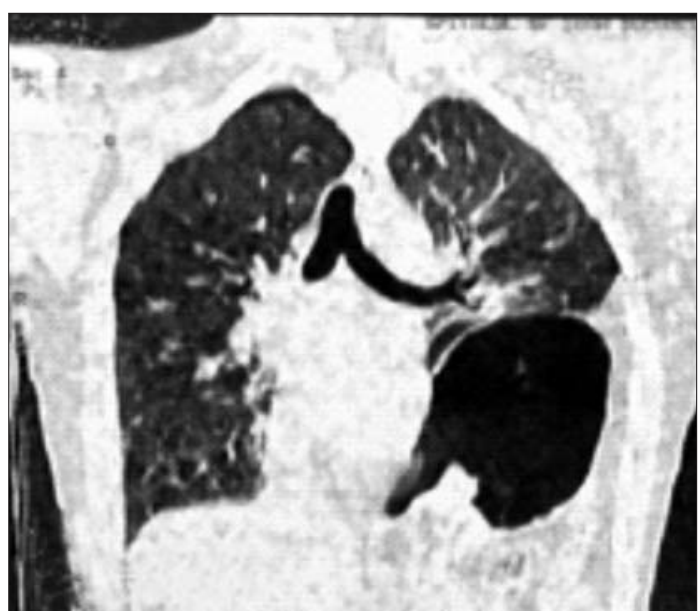

Figure 3. Thoracic computer tomography - frontal section - same aspect
All patients had multi visceral trauma, having an injury severity score (ISS) raging between 26 and 59, with an average of 34.75. The associated trauma was diverse, as shown in Table 2, whilst the clinical symptoms were almost equally prevalent and caused related (Table 3). Seven patients underwent emergency surgery. The mean time from hospital admission to surgery was 79 minutes. The only exception was the case of a female patient suffering from right thoracic trauma with subsequent haemothorax, initially drained using a chest tube. In this particular case, surgery was performed for pleural hematoma four days after the initial procedure. She under-

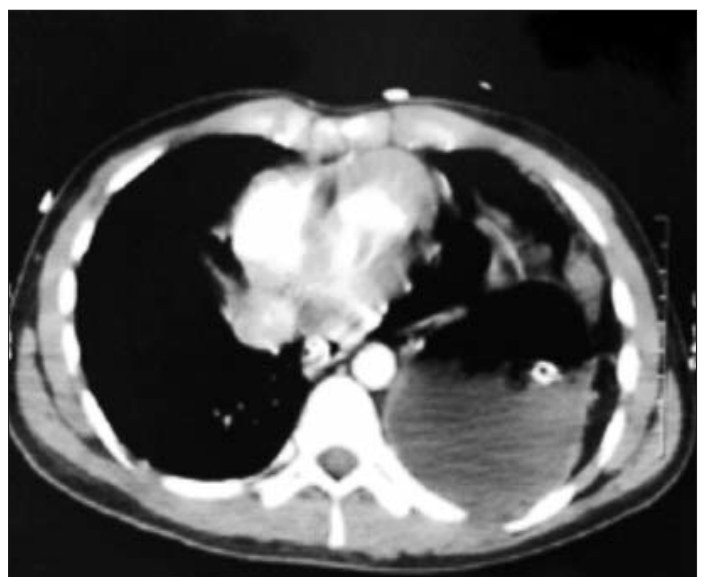

Figure 2. Thoracic computer tomography - transversal section. Note the presence of the stomach in the left pleural cavity and mediastinal displacement

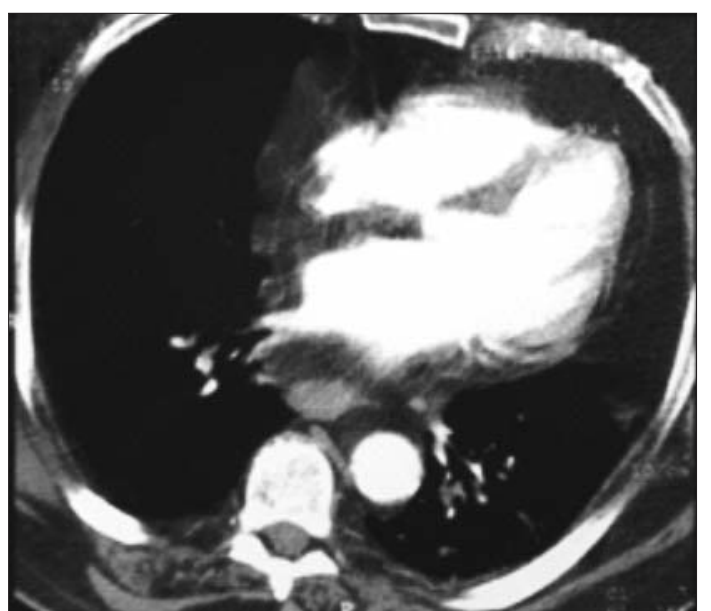

Figure 4. Thoracic computer tomography - note the disruption of the left hemidiaphragm 
Table 2. Associated lesions in patients with blunt diaphragmatic trauma

\begin{tabular}{lc}
\hline Associated lesions & No. of cases \\
\hline Spleen & 5 \\
\hline Liver & 3 \\
\hline Large bowel (contusion) & 3 \\
\hline Stomach(contusion) & 2 \\
\hline Pancreas (contusion) & 2 \\
\hline Rib fractures (2 to 4) & 3 \\
\hline Chest flail & 1 \\
\hline Hemo/pneumothorax & 8 \\
\hline Lungs (contusion) & 5 \\
\hline Severe head injury & 2 \\
\hline
\end{tabular}

went video-assisted thoracoscopy which showed right diaphragmatic rupture and grade II liver laceration with partial herniation of the right hepatic lobe. Thoracotomy was performed to better achieve trans-diaphragmatic hepatic hemostasis. Afterwards, the diaphragmatic rupture was sutured, the surgical intervention ending with pleural lavage followed by pleural drainage.

The remaining subjects, victims of blunt diaphragmatic trauma were submitted to laparotomy. In six patients ruptures of the diaphragmatic dome were found: 5 central tears, 1 marginal tear. We found a case of partial disinsertion of the lateral muscles insertions.

The particular patient having a relatively small and marginal tear of the right diaphragmatic dome, suffered intraoperative death, due to associated severe hepatic trauma, with lesions of the VIIth and VIIIth hepatic
Table 3. Associated symptomatology in patients with blunt diaphragmatic trauma

\begin{tabular}{lc}
\hline Symptomatology & No. of cases \\
\hline Hemodynamic Instability & $4(50 \%)$ \\
\hline Dyspnea & $6(75 \%)$ \\
\hline Signs of peritoneal irritation & $5(62.5 \%)$ \\
\hline
\end{tabular}

segments and central and right supra-hepatic veins avulsion which were incompatible with survival.

Blunt trauma involving the left central diaphragmatic dome usually resulted in large tears $(7-15 \mathrm{~cm}$ with a mean of $13.5 \mathrm{~cm})$ (Fig. 5A) thus associating herniation of abdominal content - Table 4. All diaphragmatic ruptures were sutured, with no prosthetic meshes being needed (Fig. 6). The associated trauma was treated accordingly: splenectomy for spleen lesions, hemostasis for liver injuries and thoracic drainage for pneumo/hemothorax. In one subject, the associated chest flail requireda second surgical procedure to be performed, consisting in surgical stabilization by use of metallic plaques.

There was a total of two intraoperative deaths in patients suffering from blunt trauma, the first being the patient with hepatic veins avulsion whereas the second patient suffered cardiac arrest upon arrival in the emergency room, having severe associated head trauma as well as severe thoracic trauma, with flail chest. Despite being successfully resuscitated in Emergency Department, she was pronounced dead 2 hours later after sustained another
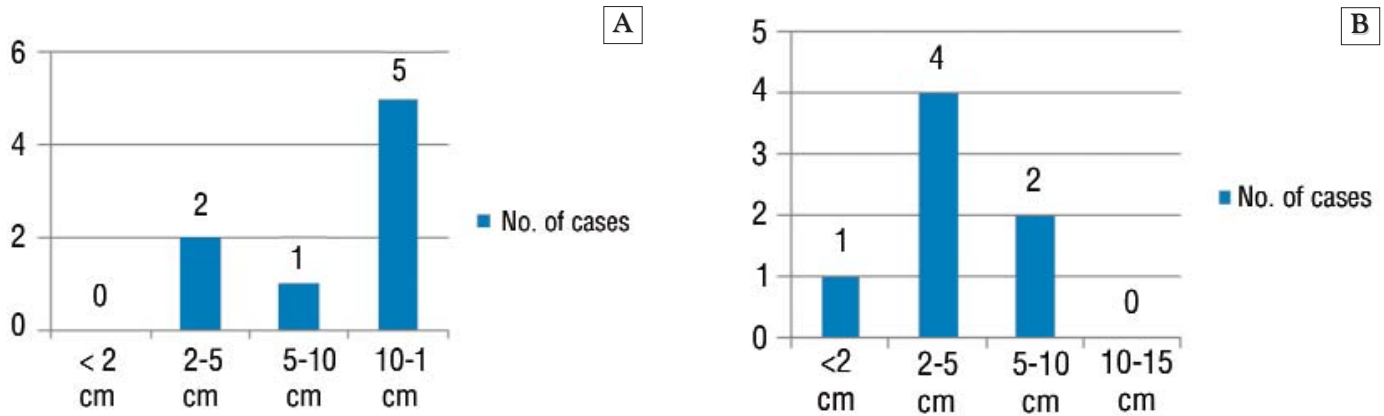

Figure 5. The diagram of diaphragmatic tear dimensions $(\mathbf{A})$ for blunt trauma (avarage $=13.5 \mathrm{~cm}$ ); (B) for penetrating trauma (avarage $=3.1 \mathrm{~cm}$ ) 
Table 4. Abdominal organs herniated secondary to blunt diaphragmatic trauma

\begin{tabular}{lc}
\hline Herniated viscera & No. of cases \\
\hline Stomach & $3(37.5 \%)$ \\
\hline Spleen & $2(25 \%)$ \\
\hline Liver & $2(25 \%)$ \\
\hline Small bowel & $1(12.5 \%)$ \\
\hline
\end{tabular}

cardiac arrest while in the operating room.

The remaining six patients in this group had a good postoperative outcome. Mean hospital stay for patients victims of blunt trauma was 16.5 days.

Postoperative complications were encountered amongst 2 patients, one developing a massive upper digestive tract haemorrhage that required surgical management while the second developed pleural hematoma which was evacuated via video assisted thoracoscopic surgery.

As far as penetrating injuries of the diaphragm are concerned, in six of our patients, the trauma was produced by physical assault. All subjects were stabbing victims except for one subject with iatrogenic diaphragmatic injury - following a chest tube insertion for hemothorax performed in another medical facility; the patients suffered blunt thoracic trauma caused by a vehicle collision. A week later she was referred to our Clinic for pleural hematoma drainage procedure. Meanwhile, she showed no sign of hemodynamic instability. Chest and abdominal CT scan revealed the chest tube passing throughout the left diaphragm into the upper pole of the spleen resulting in perisplenic hematoma. Surgical management in this patient consisted in splenectomy and diaphragmatic rupture suture via laparotomy. Thoracos-copy was afterward performed for pleural hematoma evacuation.

All stab wounds victims underwent emergency surgery, mean time from hospital admission to arrival in the operating room being 67 minutes. In only one case a diaphragmatic injury was suspected preoperatively, being suggested by paraclinical tests. Most patients were hemodynamically unstable associating signs of peritoneal irritation and different degrees of dyspnea. The injury

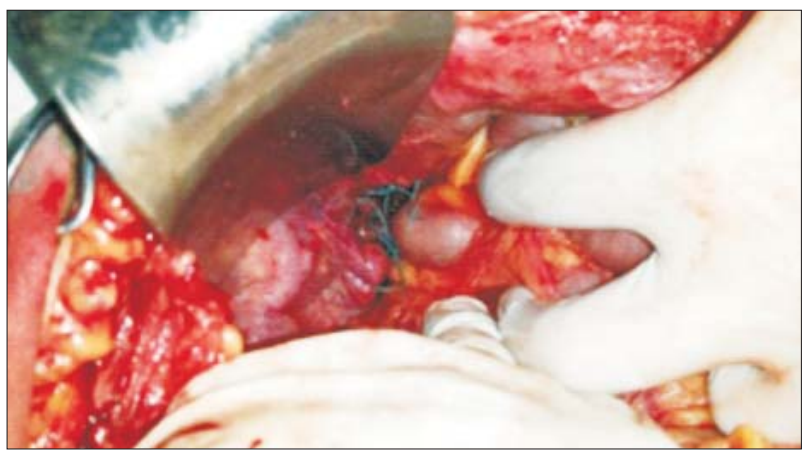

Figure 6. Diaphragmatic tear repaired with interrupted non-absorabable suture.

severity score was between 19 and 50, with a mean of 26.5.

The surgical approach was median laparotomy for all patients. All diaphragmatic ruptures were located on the left side of the diaphragm, near the diaphragm's costal insertions, producing tears between 2 and $7 \mathrm{~cm}$, with an average of $3.1 \mathrm{~cm}$ (Fig. 5B). In most cases (4 subjects), we found a single tear while the remaining 3 subjects had multiple ruptures -2 or 3 lesions. None of the mentioned subjects had subsequent intrathoracic herniation of the abdominal content. Concomitant abdominal injuries, as well as their treatment, are showed in Table 5. Except for one case of penetrating injury with extrapleural trajectory, all cases had associated hemo-and/or pneumothorax. They all required pleural drainage alone except for one subject which required both laparotomy and thoracotomy in order to obtain haemostasis on the intercostal vessels.

We found favourable postoperative outcome in 6 patients, which were considered healed at hospital discharge. The mean hospitalisation period was 19.3 days. Subjects having multiple wounds (3 cases) required prolonged hospitalization also having a higher rate of pulmonary complications such as pneumonia and pulmonary atelectasis.

An 85 years old male patient, admitted into the emergency room while in hypovolemic shock, having multiple thoracic and abdominal penetrating wounds (left pneumothorax and multiple jejunal and mesenteric injuries), wounds of the superior limbs, produced by self-aggression was the only death in this sub- 
Table 5. Lesions associated with penetrating diaphragmatic wounds

\begin{tabular}{lcc}
\hline Associated lesions & No. of cases & Treatment \\
\hline Spleen & $3(42.8 \%)$ & Splenectomy \\
\hline Liver & $1(14.2 \%)$ & Atipical resection \\
\hline Kidney & $1(14.2 \%)$ & Renoraphy \\
\hline Colon & $1(14.2 \%)$ & Colostomy \\
\hline Small bowell & $1(14.2 \%)$ & Enterectomy with anastomosis \\
\hline Omentum/mesentery & $2(28.5 \%)$ & Hemostasis \\
\hline Hemo/pneumothorax & $6(85.7 \%)$ & Pleurostomy \\
\hline
\end{tabular}

group of subjects. Death was probably produced by multiple organ failures, no postoperative complications directly related to the surgical procedure being recorded.

Radioscopy was performed for all patients having a favourable outcome, both of the blunt trauma group and penetrating trauma group. It showed hypomotility of the left diaphragm in 3 patients suffering from blunt trauma. None of the examined patients were found with diaphragmatic paralysis. Furthermore, the diaphragmatic hypomotility had no clinical repercussion.

\section{Discussions}

Our patients were equally distributed by sex as well as by the type of trauma (blunt vs penetrating trauma), as opposed to the majority of studies in which the majority of subjects were male, suffering from blunt trauma (19). As far as age, topography and injury mechanism are concerned, our data is comparable to that of other studies. More precisely, the subjects were young (mean age of 42 years), having ruptures involving mainly the left diaphragm (13/15) (Fig. 7), with road accidents as the most frequent cause of blunt trauma and stab wounds as the most frequent cause for penetrating trauma (19-21).

The higher frequency of the left hemidiaphragm involvement in the blunt traumatized patients group is explained by the protective role of the liver and theweakness of the left hemi-diaphragm at the spots of embryonic fusion (1). Some authors stated that both sides of the diaphragm are equally involved but rightside ruptures are commonly associated with severe hepatic lesions, usually incompatible with life, thus a greater pre-hospital mortality $(8,11)$. This association of lesions was also observed in our study, one of the two patients with right hemi-diaphragm rupture had also a hepatic avulsion.

The majority of road accidents victims were hemodynamically and respiratory unstable at the moment of admission. Respiratory failure was caused by the thoracic lesions (hemopneumothorax, chest flail, pulmonary contusions) and, in cases with abdominal visceral herniation, by the sudden collapse of the left lung which led to a rapidly increasing pleural pressure that produced mediastinal displacement. The result was the aggravation of the hemodynamic instability also induced by

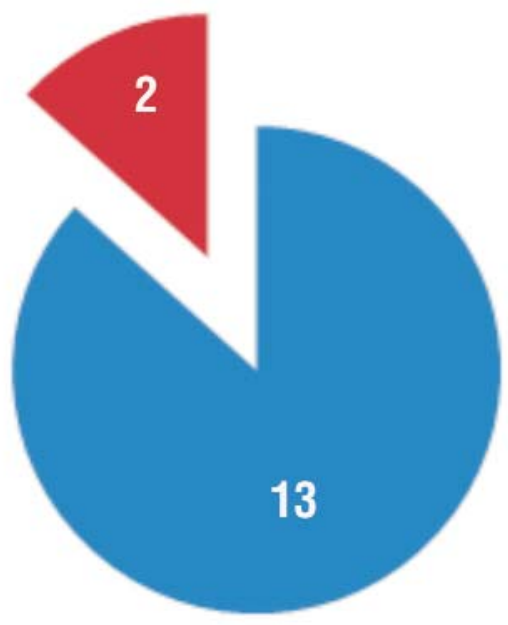

Left hemidiafragm

Right hemidiafragm

Figure 7. The topography of diaphragmatic lesions 
other visceral lesions $(1,22)$.

Preoperative imaging studies revealed the lesion in 3 of 5 cases - other 3 cases were transported directly to the operating room. The low sensitivity of these tests (between 21 and $45 \%)$ is also confirmed by other studies $(20,21)$

The central lesions of the diaphragmatic dome produced large defects, allowing abdominal visceral herniation. This was also facilitated by the negative pleural pressure. The stomach was the most frequent organ that migrated into the thorax. One patient had a combined transdiaphragmatic herniation of the stomach, spleen and small bowels. The small lateral tears were not associated with a diaphragmatic hernia. Prompt surgical intervention allowed primary direct suture of the diaphragm (before muscular atrophy and fibrosis occurred), without needing to use prosthetic meshes, even for large ruptures (8), although in some cases performing the suture was very demanding due to the irregular edges of the diaphragmatic wound.

Abdominal approach (by median laparotomy) was chosen in most of the cases (7 out of 8). It allowed a good exposure of the entire peritoneal cavity and a proper treatment of associated visceral lesions. This is the advisable surgical approach in unstable patients with abdominal visceral injuries (20). A transabdominal diaphragmatic suture was performed in right conditions for all cases. In only one instance the suture was performed by thoracotomy due to an unexpected intraoperative finding during a procedure for removal of a pleural hematoma.

Two deaths occurred in this group and were caused by severe cerebral and thoraco-abdominal injuries. All other patients had a good postoperative outcome and were considered surgical cured at the moment of discharge (Tabel 6).

In most cases, penetrating diaphragmatic lesions were produced by stabbing wounds, this being the most frequent type of open traumatic injuries during peacetime. In one case, the injury was iatrogenic, after a misplaced chest tube insertion. All lesions involved the left hemi-diaphragm. This could
Tabel 6. Associated lesions, treatment and outcome

\begin{tabular}{lrr}
\hline Characteristic & No. of cases & $\%$ \\
\hline Herniated organs & & \\
$\quad$ Liver & 2 & $13.3 \%$ \\
Spleen & 2 & $13.3 \%$ \\
Stomach & 3 & $20.0 \%$ \\
Small bowl & 1 & $6.7 \%$ \\
None & 9 & $60.0 \%$ \\
\hline Aditional abdominal lesions & & \\
Liver & 4 & $26.7 \%$ \\
Spleen & 8 & $53.3 \%$ \\
Stomach & 4 & $26.7 \%$ \\
Kidney & 1 & $6.7 \%$ \\
\hline Surgical approach & & \\
Laparotomy & 13 & $86.7 \%$ \\
Laparotomy+Thoracotomy & 1 & $6.6 \%$ \\
Thoracotomy & 1 & $6.6 \%$ \\
\hline Surgical procedure & & \\
$\quad$ Phrenoraphy & & \\
Splenectomy & 15 & $100 \%$ \\
Liver resection & 8 & $53.3 \%$ \\
Pleural dreinage & 2 & $13.3 \%$ \\
Cured & 13 & $86.7 \%$ \\
Intraoperative death & & \\
Postoperative death & 12 & $80.0 \%$ \\
\hline Outcome & 2 & $13.3 \%$ \\
\hline
\end{tabular}

be explained because the majority of aggressions were produced by frontal assault, most of the people being right-handed (23).

Preoperative imaging studies revealed the rupture in only one case, but it was highly suspected in 3 other patients who had a single wound at the base of the thorax and abdominal lesions found on computer-tomography.

The diaphragmatic tears had small dimensions and were not associated with visceral herniation. As in blunt diaphragmatic lesions, direct suture by laparotomy was successful in all cases. Only one patient demanded simultaneous thoracotomy for haemostasis for a bleeding from the intercostal vessels, and another patient required thoracoscopic removal of a pleural hematoma) (Fig. 8). For the rest of the patients, associated thoracic injuries were treated only by pleurostomy. In these cases, the pulmonary lesions were probably minimal, given the low location of the thoracic stabbing wounds, and their oblique trajectory $(23,24)$.

The only death occurred in this group was on the third postoperative day in an 85-year-old 


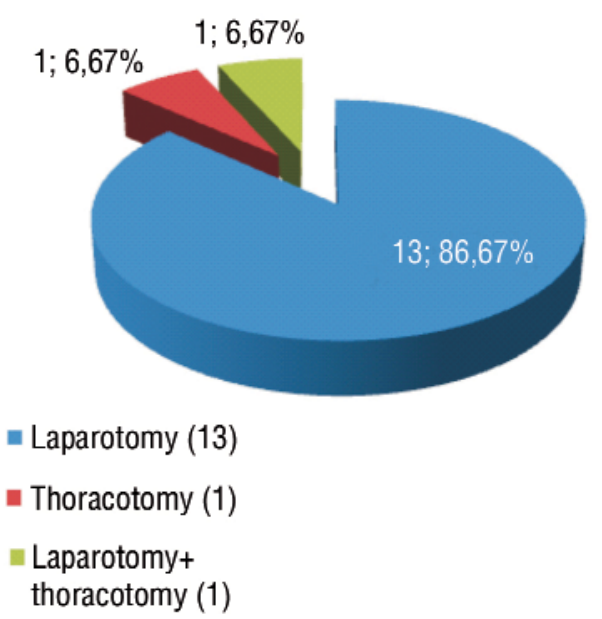

Figure 8. Surgical approach used for patients with traumatic diaphragmatic rupture

patient presented with multiple thoracic and abdominal stab wounds and hypovolemic shock. The cause of death was multiple organ failures. All other cases had a good postoperative outcome. Patients with multiple stabbing wounds had a longer period of hospitalisation due to pulmonary complications.

The mortality rate in our group was $20 \%$, similar with other studies (Tabel 6) $(8,12,13,25)$.

\section{Conclusions}

Diaphragmatic trauma is most frequently produced by motor vehicle accidents (blunt injuries) or stabbing wounds (penetrating trauma), generally being found in young patients. The left hemi-diaphragm is involved more frequently than the right-hemidiaphragm. In patients with no cranio-cerebral injury, restitutio ad integrum is possible provided that treatment is quickly implemented and guided by an accurate diagnosis. Primary diaphragmatic suture, without needing to use prosthetic meshes, is more likely to be performed in earliest possible surgical interventions, even for large tears. Laparotomy is mandatory for cases with abdominal visceral lesions; diaphragmatic repair is usually performed in adequate conditions with this surgical approach. In most cases, death is not due to the diaphragmatic trauma itself but is secondary to associated cerebral and thoraco-abdominal lesions.

Conflict of Interest: none declared

\section{References}

1. Agrusa ARG, Chianetta D, De Vita G, Frazzetta G, Di Buono G, Sorce $V$, et al. Right diaphragmatic injury and lacerated liver during a penetrating abdominal trauma: case report and brief literature review. World J Emerg Surg. 2014; 9: 33.

2. Duzgun AP, Ozmen MM, Saylam B,Coskun F. Factors influencing mortality in traumatic ruptures of diaphragm. Ulus Travma Acil Cerrahi Derg. 2008;14(2):132-8.

3. Hofmann SKM, Henne-Bruns D, Formentini A. Traumatic diaphragmatic ruptures: clinical presentation, diagnosis and surgical approach in adults. GMS Interdiscip Plast Reconstr Surg DGPW. 2012;1: Doc02.

4. Mihos P, Potaris K, Gakidis J, Paraskevopoulos J, Varvatsoulis P, Gougoutas B, et al. Traumatic rupture of the diaphragm: experience with 65 patients. Injury. 2003;34(3):169-72.

5. Waldschmidt ML, Laws HL. Injuries of the diaphragm. J Trauma. 1980;20(7):587-92

6. Panda A, Kumar A, Gamanagatti S, Patil A, Kumar S,Gupta A. Traumatic diaphragmatic injury: a review of CT signs and the difference between blunt and penetrating injury. Diagn Interv Radiol. 2014;20(2):121-8.

7. Nchimi A, Szapiro D, Ghaye B, Willems V, Khamis J, Haquet L, et al. Helical CT of blunt diaphragmatic rupture. AJR Am J Roentgenol. 2005;184(1):24-30.

8. Dwivedi SBP, Gharde P, Bhatt M, Johrapurkar Sr. Treating traumatic injuries of the diaphragm. J Emerg Trauma Shock. 2010;3(2): 173-176.

9. David BAF, Heyman L. A review diaphragmatic injury. Resp Med J. 2009:2:1-6.

10. Salah A. A-JY, El-Ghoneimy Y. Bilateral blunt diaphragmatic rupture. Lung India. 2011;(28(3)):212-215.

11. Scharff JR, Naunheim KS. Traumatic diaphragmatic injuries. Thorac Surg Clin. 2007;17(1):81-5.

12. Meyers BF, Mccabe CJ. Traumatic diaphragmatic hernia. Occult marker of serious injury. Ann Surg. 1993;218(6):783-90.

13. Petrone $P$ LA, Inaba K, Soreide K, Asensio Ja. Diaphragmatic injuries: challenges in the diagnosis and management. Trauma. 2007:9(4):227-236

14. Sacco R, Quitadamo S, Rotolo N, Di Nuzzo D,Mucilli F. Traumatic diaphragmatic rupture: personal experience. Acta Biomed. 2003;74 Suppl 2:71-3

15. Lochum S LT, Walter F, et al. Imaging of diaphragmatic injury: a diagnostic challenge? Radiographics. 2002;22:103-108.

16. Scumpia AjAD, Roman L, Vasudevan V, Ryan M. Rm, Lynn M. Diaphragmatic Rupture Secondary to Blunt Thoracic Trauma. West J Emerg Med. 2013;14(5):435-436.

17. Asensio JaPP. Diaphragmatic injury. In: C JL, editors. Current Surgical Therapy. 8th ed. Philadelphia: Elsevier Mosby Co; 2004. p. 946-955.

18. Eren S, Kantarci M, Okur A. Imaging of diaphragmatic rupture after trauma. Clin Radiol. 2006:61(6):467-77.

19. Shah R, Sabanathan S, Mearns AJ,Choudhury AK. Traumatic rupture of diaphragm. Ann Thorac Surg. 1995;60(5):1444-9.

20. Sukul DM, Kats E,Johannes EJ. Sixty-three cases of traumatic injury of the diaphragm. Injury. 1991;22(4):303-6.

21. Thiam $0 \mathrm{Kl}$, Gueye Ml, Toure Ao, Seck M, Cisse M, Diop B, et al. Traumatic diaphragmatic injuries: epidemiological, diagnostic and therapeutic aspects. Springerplus. 2016;(5):1. 
22. Okada M, Adachi H, Kamesaki M, Mikami M, Ookura Y, Yamakawa J, et al. Traumatic diaphragmatic injury: experience from a tertiary emergency medical center. Gen Thorac Cardiovasc Surg. 2012; 60(10):649-54.

23. Caloghera C. Urgențe în chirurgia toracică. In: Caloghera, editors Chirurgia de urgență. Timișoara: Ed. Artab; 1993.
24. Popovici Z. Traumatismele diafragmului. In: editors. Book Traumatismele diafragmului. Bucuresti: Editura Medicală; 1970.

25. Chughtai T, Ali S, Sharkey P, Lins M, Rizoli S. Update on managing diaphragmatic rupture in blunt trauma: a review of 208 consecutive cases. Can J Surg. 2009;52(3):177-81. 